Case Reports in
Gastroenterology
Case Rep Gastroenterol 2020;14:609-614

DOI: 10.1159/000509504

Published online: November 11, 2020

(c) 2020 The Author(s)

Published by S. Karger AG, Basel www.karger.com/crg

This article is licensed under the Creative Commons Attribution-NonCommercial 4.0 International License (CC BY-NC) (http://www.karger.com/Services/OpenAccessLicense). Usage and distribution for commercial purposes requires written permission.

\title{
Heterotopic Gastric Mucosa in the Ileum: A Rare Cause for Intussusception in Adults
}

\author{
Khaled A. Murshed ${ }^{\mathrm{a}} \quad$ Mahwish Khawar ${ }^{\mathrm{b}} \quad$ Mahir Petkar $^{\mathrm{a}}$ \\ ${ }^{a}$ Department of Laboratory Medicine and Pathology, Hamad Medical Corporation, \\ Doha, Qatar; ${ }^{b}$ Department of General Surgery, Hamad Medical Corporation, Doha, Qatar
}

\section{Keywords}

Intussusception · Heterotopic gastric mucosa $\cdot$ Intestinal obstruction · Adult

\begin{abstract}
Intussusception is the leading cause for intestinal obstruction in children. However, it accounts for only $5 \%$ of bowel obstructions in adults. Heterotopic gastric mucosa (HGM) can occur anywhere in the gastrointestinal tract; nevertheless, its occurrence in the small intestine is rare unless associated with remnants of vitelline duct (Meckel's diverticulum). Herein, we describe a case of a 33-year-old male who presented with symptoms and signs of intestinal obstruction caused by ileo-colic intussusception, in which polypoid HGM acted as the organic lead point for intussusception. Several cases of intussusception caused by HGM have been reported in pediatric age group; however, this event is exceedingly rare in adults.
\end{abstract}

(C) 2020 The Author(s)

Published by S. Karger AG, Basel

\section{Introduction}

Intussusception is defined as telescoping of a segment of the gastrointestinal tract into an adjacent one. It is believed that this condition is precipitated by any lesion or irritant within the bowel lumen that can alter normal bowel peristaltic activity $[1,2]$. Intussusception is the leading cause for intestinal obstruction in children; however, it is a rare cause for intestinal 


\section{Case Reports in Gastroenterology}

Case Rep Gastroenterol 2020;14:609-614 DOI: $10.1159 / 000509504$

(c) 2020 The Author(s). Published by S. Karger AG, Basel www.karger.com/crg

Murshed et al.: Adult Intussusception Caused by Heterotopic Gastric Mucosa

obstruction in adults [2-4]. The majority of pediatric cases are idiopathic with no specific organic cause. However, $90 \%$ of cases in adults harbor an organic lesion which serves as a lead point for intussusception [1-7].

Heterotopic gastric mucosa (HGM) or ectopic gastric mucosa, is defined as mature gastric tissue found outside the stomach where it is not normally found. HGM has been described at various locations within the gastrointestinal tract; however, this finding is rare in the small intestine unless associated with remnants of vitelline duct. In most cases, HGM remains asymptomatic. Nevertheless, it may result in several complications such as gastrointestinal bleeding and intestinal obstruction [8, 9]. Rarely, it can act as the lead point for intussusception. Here, we present an exceedingly rare case of polypoid HGM in the ileum complicated by ileo-colic intussusception in an adult male patient, which was successfully treated with surgical resection.

\section{Case Report}

A previously healthy 33-year-old man presented to the emergency department with a 2$\mathrm{h}$ history of acute right lower quadrant abdominal pain. The pain was continuous, sharp in nature, moderate in intensity and not associated with specific relieving or aggravating factors. The patient did not have nausea, vomiting, abdominal distension, change in bowel habit or bleeding per rectum. He had neither fever nor any other constitutional symptoms. There had been no similar events recorded in the past. He did not have any history of chronic medical illnesses or previous operations. Physical examination revealed a mobile, tender abdominal mass in the right lower quadrant. His anorectal and genital exams were unremarkable. His baseline laboratory investigations revealed slightly elevated white blood cell (WBC) count of $13.3 \times 10^{3} / \mu \mathrm{L}$. Computed tomography (CT) scan of the abdomen and pelvis revealed thick edematous bowel loops with a long segment of small bowel loop and mesentery invaginating into the cecum and ascending colon (Fig. 1). A preoperative diagnosis of ileo-colic intussusception was made. Laparoscopic exploration was performed, followed by conversion to laparotomy. Intraoperatively, an intraluminal polypoid lesion was found in the ileum located 100 $\mathrm{cm}$ from the ileocecal valve. Ileal segment resection with side-to-side ileo-ileal anastomosis was performed. Macroscopic examination of the resected ileal segment showed a polypoid mucosal lesion measuring $4 \mathrm{~cm}$ in maximum dimension (Fig. 2). Microscopic examination of the polypoid lesion revealed heterotopic gastric tissue occupying the full thickness of mucosa, composed of oxyntic-type gastric epithelium of parietal and mucous neck cells, and lined by foveolar epithelium exhibiting hyperplastic changes (Fig. 3, 4). No malignancy, neoplastic growth or diverticula were identified. The patient's postoperative course was uneventful. He was discharged on postoperative day 8 and is now on regular follow-up.

\section{Discussion/Conclusion}

Intussusception is defined as telescoping and invagination of a proximal bowel segment "intussusceptum" into the lumen of an adjacent distal bowel segment "intussuscipiens." It is a common cause for intestinal obstruction in the pediatric age group. However, it accounts only for $1-5 \%$ of intestinal obstruction in adults [1-5].

The majority of intussusceptions that occur in children are idiopathic. However, in adults, around $90 \%$ of cases are secondary to an underlying organic lesion acting as a lead point for 


\section{Case Reports in Gastroenterology}

Case Rep Gastroenterol 2020;14:609-614 DOI: $10.1159 / 000509504$

c) 2020 The Author(s). Published by S. Karger AG, Basel www.karger.com/crg

Murshed et al.: Adult Intussusception Caused by Heterotopic Gastric Mucosa

intussusception [1-7]. The organic cause can be benign or malignant. Benign pathologies were found to be more common in enteric intussusceptions, while malignancy is more frequent in ileo-colic and colonic intussusceptions [2-6].

HGM has been reported anywhere throughout the length of the gastrointestinal tract [813]. Its occurrence in the small intestine is rare unless associated with remnants of Meckel's diverticulum. Clinical presentation of HGM varies and depends on the location and size of the heterotopic tissue. The most common complication of HGM is intestinal mucosal ulceration with gastrointestinal bleeding [8, 9]. It can also form an intraluminal mass causing intestinal obstruction. Rarely, it can serve as a lead point for intussusception. Several cases of intussusception led by HGM in children have been reported in the literature. However, this event is exceedingly rare in adults. Nwanze et al. [10] recently described a rare case of enteric intussusception in a 24-year-old woman caused by HGM in the jejunum. In our case, the HGM was located in the ileum causing ileo-colic intussusception.

Most adult patients with intussusception usually present with nonspecific symptoms such as nausea, vomiting, abdominal pain, change in bowel habit, gastrointestinal bleeding or abdominal distension [1-5]. The classic clinical presentation triad of abdominal pain, bloody diarrhea, and palpable tender abdominal mass, which is frequently found in pediatric intussusceptions, is only present in around $10 \%$ of adult cases. Therefore, the diagnosis can be challenging preoperatively [7].

Radiological imaging can aid in the diagnosis. Abdominal CT scan is found to be the most reliable and most sensitive method for diagnosis [2-4, 14]. In addition, it can also help in identifying organic lesions and the nature of the lead points [14]. Colonoscopy can also be helpful in the diagnosis, specially to differentiate benign from malignant etiologies in distal lesions, as proposed by Wang et al. [4]. In our case, the nature of the lead point could not be determined preoperatively. An intraluminal polypoid ileal mucosal lesion was identified intraoperatively. The definitive diagnosis was reached following histopathologic examination of the resected bowel segment.

Most pediatric cases are treated with pneumatic or hydrostatic reduction. However, reduction is unwarranted in adults due to high incidence of neoplasia as a secondary cause, and reduction carries risk of dissemination of malignant cells. In adults, the treatment of choice was found to be surgical resection of the involved bowel segment according to several studies $[2,3,5,6,15,16]$.

In summary, intussusception is a rare cause for intestinal obstruction in adults. The condition is distinct in its etiology, clinical presentation, and management from pediatric intussusception. Malignancy is a common organic cause in adults that should be excluded. Our case represents an exceedingly rare cause for intussusception in adults where polypoid HGM in the ileum served as a lead point for ileo-colic intussusception, and was treated successfully with surgical resection.

\section{Acknowledgement}

The authors acknowledge the Department of General Surgery at Hamad Medical Corporation, Qatar, for providing the clinical information. The publication of this article was funded by the Qatar National Library (QNL). 


\section{Case Reports in Gastroenterology}

\section{Statement of Ethics}

Written informed consent was obtained from the patient for publication. The Institutional Review Board of the Medical Research Council, Hamad Medical Corporation, Qatar, reviewed the protocol and approved it under the number (MRC-04-20-307).

\section{Conflict of Interest Statement}

The authors have no conflicts of interest to declare.

\section{Funding Sources}

The publication of this article was funded by the Qatar National Library (QNL).

\section{Author Contributions}

K.A.M. conceived and designed the idea, performed the literature review, wrote the manuscript, and overall organized the case report; M.K. provided the clinical data and reviewed the manuscript; M.P. reviewed the manuscript and supervised the project.

\section{References}

1 Eisen LK, Cunningham JD, Aufses AH Jr. Intussusception in adults: institutional review. J Am Coll Surg. 1999;188(4):390-5.

2 Zubaidi A, Al-Saif F, Silverman R. Adult intussusception: a retrospective review. Dis Colon Rectum. 2006;49(10):1546-51.

3 Marinis A, Yiallourou A, Samanides L, Dafnios N, Anastasopoulos G, Vassiliou I, et al. Intussusception of the bowel in adults: A review. World J Gastroenterol. 2009;15(4):407-11.

4 Wang N, Cui XY, Liu Y, Long J, Xu YH, Guo RX. Adult intussusception: a retrospective review of 41 cases. World J Gastroenterol. 2009;15(26):3303-8.

5 Shenoy S. Adult intussusception: A case series and review. World J Gastrointest Endosc. 2017;9(5):220-7.

6 Sainaba SM, Ganapath AS, Sivakumar A, Gayathri AV, Yadev IP. Adult Intussusception at a Tertiary Care Center: A Retrospective Study. Niger J Surg. 2020;26(1):63-5.

7 Erkan N, Haciyanli M, Yildirim M, Sayhan H, Vardar E, Polat AF. Intussusception in adults: an unusual and challenging condition for surgeons. Int J Colorectal Dis. 2005;20(5):452-6.

8 Bhattacharya B, Jakate S, Saclarides TJ, Keshavarzian A. Gastric heterotopia presenting as a mass in jejunum. Arch Pathol Lab Med. 2003;127(4):506-7.

9 Ali SM, Ahmed AA, Saaid LA, Mohamed GM, Shah AA, Al-Tarakji M, et al. Heterotopic Gastric Mucosa Presenting as Lower Gastrointestinal Bleeding: An Unusual Case Report. Case Rep Surg. 2019;2019:5791984.

10 Nwanze J, Collins V, Crawford B, Nakanishi Y. A Case of Small Bowel Intussusception in an Adult Caused by Heterotopic Gastric Mucosa in the Jejunum: A Case Report and Review of the Literature. Am J Clin Pathol. 2018;150 suppl_1:S43.

11 Nolan HR, Glenn JB, Bozeman AP. Occult Heterotopic Gastric Mucosa as a Lead Point for Ileocolic Intussusception in an Adolescent: A Rare Finding with Inherent Diagnostic Challenges. Am Surg. 2016;82(4):E78-80

12 Kelishadi S, Chopra K, Kavic S. Heterotopic gastric mucosa: a rare cause of jejunal intussusception. Am Surg. 2011;77(9):E204-5. 
Case Reports in Gastroenterology
Case Rep Gastroenterol 2020;14:609-614

DOI: $10.1159 / 000509504$

(c) 2020 The Author(s). Published by S. Karger AG, Basel www.karger.com/crg

Murshed et al.: Adult Intussusception Caused by Heterotopic Gastric Mucosa

13 Yılmaz TU, Güneș A, Pösteki G, Güler SA. Laparoscopic treatment of ileal intussusception due to heterotopic gastric mucosa in an adult patient. Ulus Cerrahi Derg. 2014;30(1):60-1.

14 Kim YH, Blake MA, Harisinghani MG, Archer-Arroyo K, Hahn PF, Pitman MB, et al. Adult intestinal intussusception: CT appearances and identification of a causative lead point. Radiographics. 2006;26(3):733-44.

15 Reijnen HA, Joosten HJ, de Boer HH. Diagnosis and treatment of adult intussusception. Am J Surg. 1989;158(1):25-8.

16 Barussaud M, Regenet N, Briennon X, de Kerviler B, Pessaux P, Kohneh-Sharhi N, et al. Clinical spectrum and surgical approach of adult intussusceptions: a multicentric study. Int J Colorectal Dis. 2006;21(8):834-9.

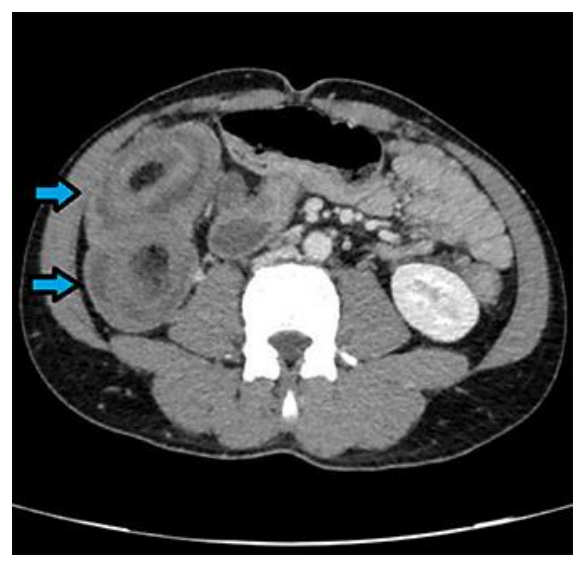

Fig. 1. CT scan of the abdomen: the blue arrows demonstrate a "target lesion" diagnostic of intussusception.

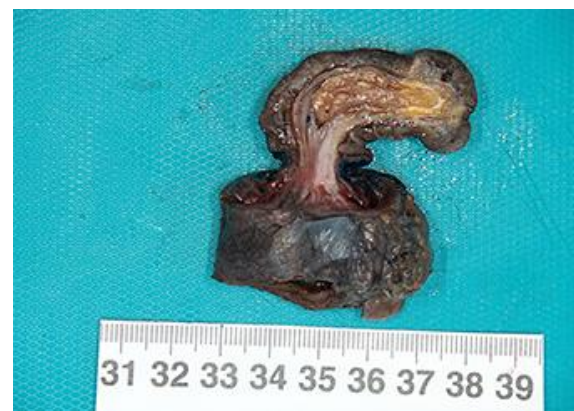

Fig. 2. Gross picture shows a cross section of the intraluminal polypoid mucosal lesion. 
Case Reports in Gastroenterology
Case Rep Gastroenterol 2020;14:609-614

DOI: $10.1159 / 000509504$

(c) 2020 The Author(s). Published by S. Karger AG, Basel www.karger.com/crg

Murshed et al.: Adult Intussusception Caused by Heterotopic Gastric Mucosa

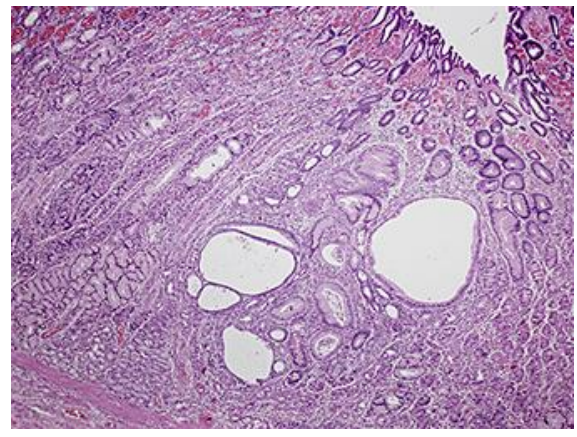

Fig. 3. Photomicrograph depicting the full thickness of mucosa occupied by an oxyntic-type gastric epithelium (H\&E stain, $\times 40)$.

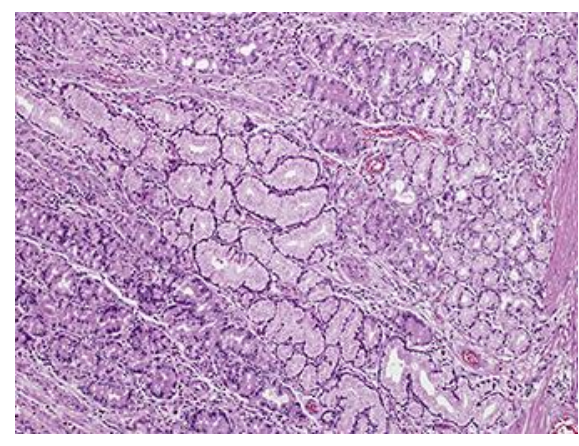

Fig. 4. High-power view shows gastric glands lined by parietal cells and others by mucous neck cells (H\&E stain, $\times 100$ ). 